\title{
Influence of tobacco, alcohol consumption, eating habits and physical activity in nursing students*
}

\author{
Pedro Manuel Rodríguez-Muñoz ${ }^{1,2,3}$ \\ (D) https://orcid.org/0000-0002-7933-952X \\ Juan Manuel Carmona-Torres ${ }^{2,4}$ \\ (D) https://orcid.org/0000-0002-7781-872X \\ María Aurora Rodríguez-Borrego $0^{1,2}$ \\ (D) https://orcid.org/0000-0002-5677-0165
}

Objective: to determine the consumption of alcohol, tobacco, eating habits, and physical activity among nursing students and to detect whether being a nursing student is a protective factor against these habits. Method: a questionnaire was used to collect information on age, academic year, sex, alcohol and tobacco consumption, physical activity, and healthy eating. An information sheet and informed consent form were given. The sample was composed of 264 students aged between 18-30 years from four academic years. Results: of the total sample, $15.5 \%$ smoked, $83.7 \%$ consumed alcoholic beverages and $97.2 \%$ consumed over the weekend. The total of $68.6 \%$ did not practice exercises and $70.5 \%$ needed changes in their diet. Conclusion: nursing students have high levels of alcohol consumption and low levels of smoking compared with other studies. The higher the academic year, the lower the age of onset of tobacco consumption. The number of men who exercised was higher, which is considered a protective factor against alcohol and tobacco consumption and is related to a healthy diet. Smoking has a negative influence on diet. The students needed to change their diet. Finally, being a nursing student is not considered a protective factor against alcohol and tobacco consumption, nor having good eating habits and exercising.

Descriptors: Alcohol; Tobacco; Eating Habits; Physical Activity; University Students; Nursing.

\section{How to cite this article}

Rodríguez-Muñoz PM, Carmona-Torres JM, Rodríguez-Borrego MA. Influence of tobacco, alcohol consumption, eating habits and physical activity in nursing students. Rev. Latino-Am. Enfermagem. 2020;28:e3230. [Access ; Available in: DOI: http:// dx.doi.org/10.1590/1518-8345.3198.3230. 


\section{Introduction}

Drugs are psychoactive substances that affects perception, mood, consciousness, and behavior ${ }^{(1)}$. Drugs with the highest prevalence of consumption in the general population are consumed at high levels by young people aged between 14 and 18 years. As of 2013, the most consumed drugs were alcohol and tobacco (78\% and $41 \%$, respectively), followed by cannabis ( $9 \%)^{(2)}$. In Spain, alcoholic beverages are the most consumed psychoactive substances among people aged between 15 and 64 years $^{(2)}$. In addition, alcohol consumption has an important relationship with mortality and disease in Spain ${ }^{(3)}$.

In general, health science students are more exposed to information about the risk factors associated with health ${ }^{(4)}$. Most nursing students are young and will become future health professionals, and several factors relate both protection and risk in terms of alcohol consumption $^{(5)}$. The Spanish Observatory on Drugs and Drug Addictions ${ }^{(2)}$ conducted a Survey on Drugs and Alcohol in Spain (EDADES). According to the results, of the people aged between 15 and 64 years, 73\% had ever consumed tobacco, $41 \%$ had used it in the last year, 38\% had used it in the last month, and $31 \%$ use it daily.

University students have a high rate of tobacco consumption, which often begins in adolescence and is strengthened at university ${ }^{(6)}$. Also, they are a vulnerable group regarding nutrition. The college period is when most students assume responsibility for their diets for the first time ${ }^{(7)}$. There is an association between nutrition and the consumption of psychoactive substances. Alcohol, for instance, inhibits food intake, while cannabis stimulates it. The consumption of psychoactive substances generates calcium deficiency ${ }^{(8)}$. The impact of alcohol consumption on the nutritional status can turn into primary and secondary malnutrition. Furthermore, alcohol interferes with the absorption of nutrients in the small intestine ${ }^{(8)}$.

According to the World Health Organization ${ }^{(9)}$, physical inactivity is the fourth leading risk factor for mortality in the world. Exercise is related to behaviors that enhance health and to a more positive selfperception $^{(10)}$. Its absence is related to the consumption of tobacco, alcohol, and other drugs.

We believe no recent studies on nursing students address their academic training acts as a protective factor against tobacco and alcohol consumption, or having good eating habits and exercising. For this reason, it is worthy investigating if health knowledge affects these different habits.

The objective is to determine alcohol and tobacco consumption, eating habits, and physical activity among nursing students, as well as whether being a nursing student is a protective factor against tobacco and alcohol consumption; or having good eating habits and exercising.

\section{Method}

This cross-sectional study asked 504 nursing students from the University of Córdoba (Spain) to participate. Of these, 305 students accepted the invitation. The data collection period was October 2016. The age range of the participants was 18 to 30 years.

Approval for this study was obtained from the Faculty of Medicine and Nursing and from the Research Ethics Committee of the province of Córdoba (Act no. 257 , ref. 3291 ). We also went to the classrooms of each undergraduate course and obtained permission from the students' professors. The students present in class were invited to participate in the study and informed of the procedure. Any possible doubts were also addressed, and an information sheet and informed consent form were handed out.

A sociodemographic questionnaire was used to collect personal data about sex, age, and academic year. A tobacco, alcohol, and physical activity questionnaire(11) was also used. The self-administered questionnaire is anonymous and has direct questions. It consists of three scales: tobacco consumption, alcohol consumption, and physical activity. The variables were frequency, hour of the first cigarette, age of onset, tobacco and alcohol consumption background of family or friends, antismoking campaigns, social pressure, type of alcoholic beverage, type of physical activity and passage through the university. This instrument is a useful tool to assess life habits of university students ${ }^{(11)}$.

The Spanish diet quality according to the healthy eating index (IASE) was used to determine the diet quality of the study population(12). It is based on the methodology of the North American Healthy Eating Index $(\mathrm{HEI})^{(13)}$. It consists of 10 variables that represent the food groups consumed daily, weekly, and occasionally, as well as the variety of the diet according to the recommendations proposed by the Spanish Society of Community Nutrition (SENC) ${ }^{(12)}$. The sum of the score of each variable can be used to classify a person's diet into three categories: "healthy" if the score is higher than 80 , "needs changes" if the score is lower than or equal to 80 and higher than 50 , and "inadequate" if it is lower than or equal to $50^{(12,14)}$. This questionnaire was applied in Spanish ${ }^{(12)}$ and to university populations ${ }^{(14)}$.

The results were analyzed using Statistical Package for the Social Sciences (SPSS) v.23, a program for statistical analysis. The qualitative variables are described as counts ( $\mathrm{n}$ ) and percentages (\%), and quantitative variables are summarized as the mean $(\mathrm{m})$ 
and standard error of the mean (SD). Different variables are related using the $x^{2}$ test in the case of qualitative variables and an analysis of variance for quantitative data. All contrasts were bilateral, and in all statistical tests, values were considered significant if their confidence level was $95 \%(p=0.05)$.

\section{Results}

At first, 305 students agreed to participate in the study, but 28 were not within the age range and 13 did not fill out the whole questionnaire (they only filled out sociodemographic questions). Therefore, the final sample was composed of 264 students. The mean age (SD) was 20.79 years. There were 52 participants in their freshman year, 58 were sophomore, 59 were in their junior year, and 95 were seniors. The sample was $16.7 \%$ men and $83.3 \%$ women.

Regarding tobacco consumption, $84.5 \%$ of the students did not smoke, of these, $67 \%$ had never smoked. Furthermore, 7.2\% smoked daily. Of the $15.5 \%$ who smoked, $12.5 \%$ smoke fewer than 10 cigarettes per day. As to sex, $20.5 \%$ of men and $14.6 \%$ of women smoked. A total of $4.9 \%$ started smoking for the first time between the ages of 13 and $15,11.7 \%$ started between 16 and 18 years, and $7.2 \%$ started at 18 . No student smoked for the first time before the age of 13 . Significant differences were observed in relation to the academic year: the higher the year, the lower the age of onset of smoking. Among those in their senior year, $10.5 \%$ $(p=0.037)$ started smoking between the ages of 13 and 15 , while among those in their freshman year, nobody started before the age of 16 . After completing university education, $2.7 \%$ of nursing students at the University of
Córdoba claim to have quit smoking, $6.1 \%$ smoke less, $6.4 \%$ have not changed, and $4.2 \%$ smoke more.

Regarding the environment, $72.3 \%$ spent most of the day with someone who smokes sometimes. Significant differences were found among sophomores, in which $48.3 \%(p=0.013)$ of students do not have contact with smokers. Regarding the intensity of campaigns against smoking, $47.7 \%$ considered it low, $49.6 \%$ considered it normal, and $2.7 \%$ considered it excessive. Among freshmen, $50 \%$ considered the intensity to be low compared with $37.9 \%$ of seniors.

As to alcohol consumption, $83.7 \%$ of nursing students at the University of Córdoba drink. Of this percentage, $23.1 \%$ drink one day or less often per month, $48.1 \%$ drink 2 to 4 days per month, $11 \%$ drink 2 to 3 days per week, and $1.5 \%$ drink 4 or more days per week. Most students in their junior year consumed alcoholic beverages $(93.2 \% ; p=0.026)$, followed by those in their senior year $(90.5 \%)(p=0.026)$. Significant differences were found between the last two years of the nursing course and the first two.

A total of $97.2 \%$ students who drink alcohol report that they consume a greater amount on weekends (including Thursday). As to sex, $75 \%$ of men consume alcohol compared with $85.5 \%$ of women. Regarding the type of alcoholic drink, $23.9 \%$ of students usually consume wine, with $19.3 \%$ drinking 1-3 glasses per week. A total of $42.8 \%$ students usually consume beer, with $35.6 \%$ drinking between 1 and 3 medium-sized bottles per week. Of the sample, $36 \%$ regularly consume combined drinks, with $27.3 \%$ drinking between 1 and 3 times a week. Table 1 shows the consumption of wine, beer, and combined drinks among students by academic year.

Table 1 - Characteristics: alcohol and tobacco consumption by academic year $(n=264)$. Córdoba, ES, España, 2016

\begin{tabular}{|c|c|c|c|c|c|}
\hline \multirow{2}{*}{ Variable } & \multicolumn{4}{|c|}{ Academic Year } & \multirow{2}{*}{ P value* } \\
\hline & Fr. year $(n=52)$ & So. year $(n=58)$ & Jr. year $(n=59)$ & Sr. year $(n=95)$ & \\
\hline Tobacco consumption & & & & & 0.590 \\
\hline He/She does not smoke, has never smoked & $35(67.3 \%)$ & $41(70.7 \%)$ & $43(72.9 \%)$ & $58(61.1 \%)$ & \\
\hline He/She does not smoke but had smoked & $11(21.2 \%)$ & $10(17.2 \%)$ & $7(11.9 \%)$ & $18(18.9 \%)$ & \\
\hline He/She smokes, but not daily & $3(5.8 \%)$ & $3(5.2 \%)$ & $7(11.9 \%)$ & $9(9.5 \%)$ & \\
\hline He/She smokes daily & $3(5.8 \%)$ & $4(6.9 \%)$ & $2(3.4 \%)$ & $10(10.5 \%)$ & \\
\hline Number of cigarettes consumed per day: & & & & & 0.554 \\
\hline Fewer than 10 & $6(11.5 \%)$ & $6(10.3 \%)$ & $7(11.9 \%)$ & $14(14.7 \%)$ & \\
\hline Between 11 and 20 & - & - & $1(1.7 \%)$ & $3(3.2 \%)$ & \\
\hline Between 21 and 30 & - & $1(1.7 \%)$ & - & - & \\
\hline \multicolumn{6}{|l|}{ Smokers on the environment: } \\
\hline No smokers on the environment & $10(19.2 \%)$ & $28(48.2 \%)$ & $15(25.4 \%)$ & $20(21 \%)$ & 0.013 \\
\hline Age of onset of tobacco consumption & & & & & 0.037 \\
\hline Between $13-15$ years & - & $(1.7 \%)$ & $(3.4 \%)$ & $(10.5 \%)$ & \\
\hline Alcohol consumption & & & & & 0.026 \\
\hline He/She does not drink alcohol & $14(26.9 \%)$ & $15(25.9 \%)$ & $4(6.8 \%)$ & $10(10.5 \%)$ & \\
\hline Once or less a month & $7(13.5 \%)$ & $17(29.3 \%)$ & $15(25.4 \%)$ & $22(23.2 \%)$ & \\
\hline 2-4 times/month & $26(50 \%)$ & $22(37.9 \%)$ & $29(49.2 \%)$ & $50(52.6 \%)$ & \\
\hline 2-3 times/week & $5(9.6 \%)$ & $4(6.9 \%)$ & $10(16.9 \%)$ & $10(10.5 \%)$ & \\
\hline 4 or more times/week & - & - & $1(1.7 \%)$ & $3(3.2 \%)$ & \\
\hline
\end{tabular}


Table 1 - (continuation)

\begin{tabular}{|c|c|c|c|c|c|}
\hline \multirow{2}{*}{ Variable } & \multicolumn{4}{|c|}{ Academic Year } & \multirow{2}{*}{ P value* } \\
\hline & Fr. year $(n=52)$ & So. year $(n=58)$ & Jr. year $(n=59)$ & Sr. year $(n=95)$ & \\
\hline Days of the week of greater alcohol consumption: & & & & & 0.003 \\
\hline Weekends (including Thursdays) & $38(73.1 \%)$ & $38(65.5 \%)$ & $55(93.2 \%)$ & $79(83.2 \%)$ & \\
\hline Consumption of wine as usual & $11(21.2 \%)$ & $11(18.9 \%)$ & $15(25.4 \%)$ & $26(27.4 \%)$ & 0.297 \\
\hline Consumption of beer as usual & $16(30.8 \%)$ & $20(34.5 \%)$ & $30(50.9 \%)$ & $47(49.5 \%)$ & 0.136 \\
\hline Consumption of combined drinks as usual & $20(38.4 \%)$ & $16(27.5 \%)$ & $23(39 \%)$ & $36(37.9 \%)$ & 0.335 \\
\hline Personal opinion about consumption & & & & & 0.007 \\
\hline $\mathrm{He} / \mathrm{She}$ thinks he/she does not drink much & $(28.9 \%)$ & $(39 \%)$ & $(8.5 \%)$ & $(30.5 \%)$ & \\
\hline University stage: & & & & & 0.017 \\
\hline It has not influenced him/her, still does not drink alcohol & $17(32.7 \%)$ & $17(29.3 \%)$ & $9(15.2 \%)$ & $22(23.1 \%)$ & \\
\hline $\mathrm{He} /$ she consumes less alcohol & $3(5.8 \%)$ & $8(13.8 \%)$ & $6(10.2 \%)$ & $18(18.9 \%)$ & \\
\hline
\end{tabular}

$* \mathrm{p}$ value $=$ Chi-Square Test

Of the students, $49.2 \%$ began to consume alcoholic beverages between the ages of 16 and $18,20.5 \%$ began between 13 and 15 years, and $16.7 \%$ began at 18 . No student started drinking alcohol before the age of 13 . The amount of alcohol that students believe they drink was significantly different among junior students, with $8.5 \%(p=0.007)$ believing that they do not drink much, while in other years, the percentage oscillates between 29 and 39\%.

The drinking habits of $24.3 \%$ of the students have been modified after they entered university, with some consuming less alcohol (13.3\%), not drinking at all $(2.7 \%)$, and drinking more $(8.3 \%)$. There are significant differences between the academic years. In the junior year, $15.2 \%$ of the students $(p=0.017)$ state they have not changed their drinking habits after entering university; they still do not consume alcohol. In other years, the percentage ranges from 23 to $33 \%$. There are also significant differences between freshmen and seniors. In the freshman year, $5.8 \%$ of students consume less alcohol compared with the $18.9 \%$ of those in their senior year (Table 1).

Among the participants, $68.6 \%$ of nursing students exercised (Table 2). Women were more physically inactive $(35.2 \%)$ than men $(11.4 \%)$. Most university students $(52.2 \%)$ performed resistance activities, and $32.8 \%$ performed several types of physical activities (Table 2). Of the $68.6 \%$ students who exercised, $35.6 \%$ did it between 3 and 5 days a week, and $23.1 \%$ did it twice a week.

Table 2 - Characteristics: physical activity and diet by academic year $(n=264)$. Córdoba, ES, Spain, 2016

\begin{tabular}{|c|c|c|c|c|c|}
\hline \multirow{2}{*}{ Variable } & \multicolumn{4}{|c|}{ Academic Year } & \multirow{2}{*}{ P value* } \\
\hline & Fr. $(n=52)$ & So. $(n=58)$ & Jr. $(n=59)$ & Sr. $(n=95)$ & \\
\hline $\mathrm{He} /$ she exercises & $33(63.5 \%)$ & $37(63.8 \%)$ & $45(76.3 \%)$ & $66(69.5 \%)$ & 0.407 \\
\hline University stage: & & & & & 0.002 \\
\hline $\mathrm{He} /$ she exercises less & $20(38.5 \%)$ & $12(20.7 \%)$ & $7(11.9 \%)$ & $14(14.7 \%)$ & \\
\hline He/she exercises more & $7(13.5 \%)$ & $22(38 \%)$ & $22(37.2 \%)$ & $33(34.7 \%)$ & \\
\hline Diet quality: & & & & & 0.418 \\
\hline Healthy diet & $10(19.2 \%)$ & $15(25.9 \%)$ & $19(32.2 \%)$ & $23(24.2 \%)$ & \\
\hline It needs changes & $39(75 \%)$ & $41(70.7 \%)$ & $40(67.8 \%)$ & $66(69.5 \%)$ & \\
\hline Inadequate & $3(5.8 \%)$ & $2(3.4 \%)$ & - & $6(6.3 \%)$ & \\
\hline
\end{tabular}

About entering university, $48.1 \%$ of students said their exercise habits had not changed and that they continued performing the same physical activity, while $31.8 \%$ reported exercising more. Significant differences were observed in the freshman year, as $38.5 \%$ of students $(p=0.002)$ reported exercising less. Freshman students $(13.5 \% ; p=0.002)$ said they exercised more, while in the other years, the results were between 34 and $38 \%$, with a particular difference among seniors (38.5\%). Table 2 shows these results.

A total of $70.5 \%$ nursing students needed changes in their diet, $25.4 \%$ of students had a healthy diet, and $4.2 \%$ had an inadequate diet (Table 2 ). As to sex, $36.4 \%$ of men and $23.2 \%$ of women had a healthy diet and $59.1 \%$ of men and $72.7 \%$ of women needed changes in their diet.

\section{Discussion}

According to the data, $83.7 \%$ of nursing students at the University of Córdoba (Spain) consume alcoholic beverages. These results are similar to previous studies on Spanish university students(11,15-18). Alcohol consumption among nursing students in this study is higher than that in other studies with nursing students $^{(19-20)}$ and international studies with university 
students from Canada(21), Chile ${ }^{(22)}$, Hungary, Lithuania, Slovakia(23), Nigeria(24), and Europe in general(25). Consumption is slightly higher when compared with young people aged between 14 and 18 years $^{(2)}$.

Among the students who drink alcohol, $82.2 \%$ consume it fewer than 4 days a week. Students of Córdoba have a weekly consumption similar to those of other studies ${ }^{(11)}$. The most commonly consumed beverage is beer, as in other studies(26-29). This could be due to its low cost and easy access ${ }^{(26)}$.

Seniors drink more alcohol than freshman students, which was found in other studies(22,30). Therefore, being a nursing(31-32) or health sciences ${ }^{(15)}$ student is not a protective factor against alcohol consumption, since there are also more consumers. Most students (97.2\%) drink more alcohol on weekends, including Thursday, as other studies also indicate ${ }^{(11,33-34)}$. This may be due to a binge drinking pattern, which lasts few hours and happens on weekends ${ }^{(2,35)}$. The percentage of women who consume alcohol is higher than that of men, which does not coincide with other studies(15). This may be due to the greater episodic alcohol consumption among women ${ }^{(15)}$.

Of the university students who do not consume alcohol, $60.5 \%$ exercise. The data indicate that physical activity could be considered a protective factor against alcohol consumption, as mentioned in other studies ${ }^{(10,36)}$. Nursing students at Córdoba show lower levels of tobacco consumption compared with the general population of 15 to 64-year-olds and with young people aged between 14 and 18 years $^{(2)}$. The percentage of smokers in this study $(15.5 \%)$ is lower than those obtained in general students by the University of Valencia $(24.83 \%)^{(37)}$, University of Barcelona $(23.4 \%)^{(38)}$, University of Vigo $(31.7 \%)^{(15)}$, University of Leon $(29.3 \%)^{(39)}$, and University of Texas $(26.2 \%)^{(40)}$. It is also lower than those obtained in nursing students from the University of Lima (Peru) $(17 \%)^{(41)}$, Australia $(21 \%)^{(42)}$, Turkey $(22.7 \%)^{(43)}$ and $(25.2 \%)^{(44)}$, Barcelona $(35.1 \%)^{(38)}$, and University of Chile $(23.7 \%)^{(22)}$.

As in other studies, the tobacco consumption increased after students entered the university ${ }^{(11,30,45-46)}$. Seniors smoked more than freshmen. There were more smokers in the senior year $(14.2 \%$ more than in the freshman year), which also occurred with alcohol. Thus, being a nursing ${ }^{(31-32)}$ or health sciences ${ }^{(15)}$ student is not a protective factor against tobacco consumption.

The higher the schooling level, the lower the age of onset of smoking ( $p=0.037)$. This early onset of smoking could lead to the use of other types of drugs, such as alcohol and illegal drugs ${ }^{(40)}$. As other studies indicate ${ }^{(47-51)}$, one of the protective factors against smoking is physical activity. This is in agreement with our study, in which $83.9 \%$ of students who exercise do not smoke currently.

Of the students included in this study, $72.3 \%$ spent most of the day with a person who smokes occasionally, although only $15.5 \%$ of all students smoked. Therefore, having contact with smokers is not a risk factor, as other studies claim ${ }^{(40,47,52)}$. Men smoke more than women. These data coincide with that of other studies ${ }^{(15,38)}$ but disagrees with others ${ }^{(40,53)}$. These differences between studies may be due to the different reasons why people smoke. Women smoke mainly because they believe it helps them stay thin and makes them feel good(40), while men smoke for competition and social relationships ${ }^{(40,53)}$.

In this study, $68.6 \%$ of nursing students exercised compared with $31.4 \%$ who did not. The number of students that exercise is higher than in other studies $^{(11,54-55)}$ and is similar to the result obtained in studies carried out by the University of United Arab Emirates $^{(56)}$ and University of the Basque Country ${ }^{(57)}$. As to the type of physical activity, more than a half of students practiced resistance activities (52.2\%), followed by those who practice two or more types of physical activity $(32.8 \%)$.

Of the students in this study, $31.8 \%$ said they exercised more after entering university. This situation can also be seen according to the academic year, since $34.7 \%$ of students in their senior year said they exercised more compared with $13.5 \%$ of those in their freshman year $(p=0.002)$. These results indicate that the students of Córdoba exercise more after entering the university. This may be due to individual motivations, such as competition, personal capacity, health improvement, being with friends, and interacting with others ${ }^{(58-59)}$. These motivations can appear at the university stage.

Men exercise more than women, as observed in other studies as well(15,53-54,60). Women exercise mainly out of concern for health and to improve their physical appearance $^{(60)}$. Furthermore, it is in the first stage of adulthood when they most often leave physical activity(53), which usually concurs with the university stage.

The students had a better food pattern than those in other studies on nursing students from Spain ${ }^{(14)}$, the general population, and people aged between 16 and 24 years ${ }^{(12)}$. A total of $25.4 \%$ nursing students had a healthy diet, and $70.5 \%$ needed changes in their diet. In a study conducted by the Albacete Faculty of Nursing(14), no student had a healthy diet, and 91.25\% needed changes.

Among the students who had a healthy diet, $74.6 \%$ exercise compared with $25.4 \%$ that do not. Therefore, it seems that physical activity is related to a healthy food pattern, as found in other studies ${ }^{(53,61)}$. With non-sedentary habits, students seem to have regular meal schedules ${ }^{(61)}$. 
In comparison, $83.5 \%$ of non-smokers had a healthy diet versus $16.5 \%$ of smokers. In this study, smoking had a negative effect on food, as other studies have also reported ${ }^{(62-63)}$. A reduced variety of foods was also emphasized ${ }^{(62)}$.

One limitation of this study is the difficulty of generalizing the results because the sample is limited to nursing students of the University of Córdoba. As usual, another weakness of this type of study is the selfreported information and the cross-sectional design. It is important to pay attention to the reasons why people smoke and drink alcohol in order to develop personalized interventions and promote healthy living habits. Physical activity could be encouraged at the university by providing motivation and resources. It would also be interesting to assess where students live (e.g., in shared flats or at home with parents) to determine how much it affects the variables studied, especially eating habits. In addition, questionnaires with open questions could have been provided for students to express their opinions. This circumstance could offer different themes related to the study. Other university students could also be polled in addition to nursing or health care students at the University of Córdoba. This would allow a fair comparison and make a clear delineation of whether being a nursing student is a protective factor compared with non-health care students.

\section{Conclusion}

In conclusion, nursing students of the University of Córdoba have a high consumption of alcohol and a low consumption of tobacco when compared with other studies. Beer is the most commonly consumed drink, and most students drink more on weekends (including Thursday). As to nutrition, they have a good diet when compared with other studies. Physical activity is related to healthy dieting, and being a smoker has a negative effect on nutrition. Seniors drink more alcohol, smoke more, and exercise more than freshman students. Moreover, the higher the academic year, the lower the age of onset of tobacco consumption. Regarding sex, women drink more alcohol and men smoke and exercise more. The profile of university students can be established as involving high consumption of alcohol, less tobacco consumption, regular physical activity, and they needed diet changes. Finally, being a nursing student cannot be considered a protective factor against alcohol and tobacco consumption; or having good eating habits and exercising.

This study helps us understand the habits of alcohol and tobacco consumption, the practice of physical activity and eating habits in nursing students, who during their studies receive training in healthy habits. As future nursing professionals, they put their health knowledge into practice, since in the future they will have to give advice on healthy habits, and, on the other hand, they will treat patients with addiction to tobacco or alcohol. It would be interesting to reinforce this knowledge and spread it, from the academic period, seminars or courses so that the nursing students promote healthy habits not among themselves but also among other university students in other branches of knowledge or general population.

\section{References}

1. Rivera JV, Vance EG, Rushton WF, Arnold JK. Novel Psychoactive Substances and Trends of Abuse. Crit Care Nurs Q. 2017 Oct-Dec;40(4):374-82. doi: 10.1097/ cnq. 0000000000000174 .

2. Observatorio Español de la Droga y las Toxicomanías, OEDT. Informe 2015. Alcohol, tabaco y drogas ilegales en España. Madrid: Delegación del Gobierno para el Plan Nacional sobre Drogas [Internet]. 2016; [Acceso 17 oct 2017]. Disponible en: http:// http://www.pnsd. msssi.gob.es/profesionales/sistemasInformacion/ informesEstadisticas/pdf/INFORME_2015.pdf

3. Pulido J, Indave-Ruiz BI, Colell-Ortega E, RuizGarcía M, Bartroli M, Barrio G. Population based studies on alcohol related harm in Spain. Rev Esp Salud Publica. 2014;88(4):493-513. doi: 10.4321/S113557272014000400005.

4. Segura LS, Cáliz NE. Illicit and licit drug consumption by UDCA's college students. Rev UDCA Actualidad \& Divulgación Científica. [Internet]. 2015 [cited Aug 18, 2016];18(2):311-9. Available from: http://omextad. salud.gob.mx/contenidos/investigaciones/CONSUMO.pdf 5. Ortega-Pérez CA, Costa-Junior ML, Pereira Vasters G. Epidemiological Profile of Drug Addiction in College Students. Rev. Latino-Am. Enfermagem. 2011 May-Jun;19(Spe):665-72. doi: 10.1590/S010411692011000700002.

6. Martínez-Hernáez Á, Marí-Klose M, Julià A, Escapa $S$, Marí-Klose $\mathrm{P}$, DiGiacomo $\mathrm{S}$. Adolescent daily smoking, negative mood-states and the role of family communication. Gaceta Sanit. 2012;26(5):421-8. doi: 10.1016/j.gaceta.2011.09.030.

7. Durán Agüero S, Bazaez Díaz G, Figueroa Velásquez $\mathrm{K}$, Berlanga Zuñiga MR, Encina Vega C, Rodríguez Noel MP. Comparison between the quality of life and nutritional status of nutrition students and those of other university careers at the Santo Thomas University in Chile. Nutr Hosp. 2012;27(3):739-46. doi: 10.3305/ nh.2012.27.3.5746

8. Moreno Otero R, Cortés JR. Nutrition and chronic alcohol abuse. Nutr Hosp. [Internet]. 2008 Mayo [cited 
Oct 22, 2018];23(Suppl 2):3-7. Available from: http:// scielo.isciii.es/scielo.php?script=sci_arttext\&pid=S0212$16112008000600002 \& \operatorname{lng}=$ es.

9. World Health Organization (WHO). Global recommendations on physical activity for health. Geneva: World Health Organization. [Internet]. 2010 [cited July 19, 2018]. Available from: http://www.who.int/ dietphysicalactivity/publications/9789241599979/es/

10. Huéscar E, Cervelló E, Llamas L, Moreno-Murcia JA. Conductas de consumo de alcohol y tabaco y su relación con los hábitos saludables en adolescentes [Behaviors of alcohol and tobacco consumption and their relationship with healthy habits in adolescents]. Behav Psychol/Psicol Conductual. [Internet]. 2011 [cited May 12, 2018];19(3):523. Available from: https://dialnet. unirioja.es/servlet/articulo?codigo $=3786034$

11. Pastor AM, Galindo SB, Hernandez ML, Navarro AM, Bernal CC, Aleman JA. Association between the consumption of tobacco and alcohol and physical exercise while at university. Atención Primaria. 2009 Oct;41(10):558-63. doi: 10.1016/j.aprim.2009.01.006 12. Norte Navarro AI, Ortiz Moncada R. Spanish diet quality according to the healthy eating index. Nutr Hosp. 2011 Mar-Apr;26(2):330-6. doi: 10.1590/s021216112011000200014.

13. Kennedy ET, Ohls J, Carlson S, Fleming K. The Healthy Eating Index: design and applications. J Am Diet Assoc. 1995 Oct;95(10):1103-8. doi: 10.1016/s00028223(95)00300-2.

14. Cervera Burriel F, Serrano Urrea R, Vico Garcia C, Milla Tobarra M, Garcia Meseguer MJ. Food habits and nutritional assessment in a university population. Nutr Hosp. 2013 Mar-Apr;28(2):438-46. doi: 10.3305/ nh.2013.28.2.6303.

15. Molina AJ, Varela V, Fernandez T, Martin V, Ayan C, Cancela JM. Unhealthy habits and practice of physical activity in Spanish college students: the role of gender, academic profile and living situation. Adicciones. 2012 [cited Jan 22, 2018];24(4):319-27. Available from: https://www.redalyc.org/articulo.oa?id=289124639006 16. Tirado Morueta R, Aguaded Gómez JI, Marín Gutiérrez I. Factores de protección y de riesgo del consumo de alcohol en alumnos de la universidad de Huelva [Factors of protection and risk of alcohol consumption in students of the University of Huelva]. Health Addic. [Internet]. 2009; [cited Jan 22, 2018];9(2):165-83. Available from: https://core.ac.uk/download/pdf/60651183.pdf 17. Viña CM, Herrero M. El consumo de sustancias psicoactivas en estudiantes de Psicología de la Universidad de la Laguna [The consumption of psychoactive substances in students of Psychology at the University of La Laguna]. Int J Clin Health Psychol. [Internet]. 2004 [cited Jan 23, 2018];4(3):521-36. Available from: http:// www.redalyc.org/comocitar.oa?id=33740305
18. Basurto FZ, Ríos FL, Montes JMG, Moreno AM. Self-reported consumption of alcohol and other drugs in the university population. Electr J Res Educ Psychol. [Internet] 2011 [cited Jan 23, 2018];9(23):113-32. Available from: https://dialnet.unirioja.es/servlet/ articulo?codigo $=3678184$

19. Boulton M, O'Connell KA. Nursing Students' Perceived Faculty Support, Stress, and Substance Misuse. J Nurs Educ. 2017 Jul 1;56(7):404-11. doi: 10.3928/01484834-20170619-04.

20. Matute RC, Pillon SC. Alcohol consumption by nursing students in Honduras. Rev. Latino-Am. Enfermagem. 2008;16:584-9. doi: 10.1590/S010411692008000700013.

21. Muli N, Lagan BM. Perceived determinants to alcohol consumption and misuse: a survey of university students. Perspect Public Health. 2017 Nov;137(6):326-36. doi: $10.1177 / 1757913917710569$

22. Romero MI, Santander J, Hitschfeld MJ, Labbé M, Zamora V. Smoking and alcohol drinking among medical students at the Pontificia Universidad Católica de Chile. Rev Méd Chile. 2009;137(3):361-8. doi: 10.4067/ S0034-98872009000300006.

23. Helmer SM, Sebena R, McAlaney J, Petkeviciene J, Salonna F, Lukacs A, et al. Perception of High Alcohol Use of Peers Is Associated With High Personal Alcohol Use in First-Year University Students in Three Central and Eastern European Countries. Subst Use Misuse. 2016 Jul 28;51(9):1224-31. doi: 10.3109/10826084.2016.1162810.

24. Ajayi AI, Owolabi EO, Olajire OO. Alcohol use among Nigerian university students: prevalence, correlates and frequency of use. BMC Public Health. 2019 Jun 13;19(1):752. doi: 10.1186/s12889-019-7104-7.

25. Cooke R, Beccaria F, Demant J, Fernandes-Jesus M, Fleig L, Negreiros J, et al. Patterns of alcohol consumption and alcohol-related harm among European university students. Eur J Public Health. 2019 May 11. doi: 10.1093 / eurpub / ckz067.

26. Galan I, Gonzalez MJ, Valencia-Martin JL. Alcohol drinking patterns in Spain: a country in transition. Rev Esp Salud Publica. 2014 Aug;88(4):529-40. doi: 10.4321/S1135-57272014000400007

27. Barbosa Ramírez C, Bríñez Horta A, Caycedo Espinel C, Méndez Heilman M, Oyuela Vargas R. Elements for prevention programs in alcohol consumption by university students. Universitas Psychol. [Internet] 2012 [cited Oct 30, 2017];11(1):131-45. Available from: http:// www.scielo.org.co/pdf/rups/v11n1/v11n1a11.pdf

28. Choi HJ, Lu Y, Schulte M, Temple JR. Adolescent substance use: Latent class and transition analysis. Addictive Behav. 2018 Feb;77:160-5. doi: 10.1016/j. addbeh.2017.09.022. 
29. Pascual Pastor F. Imagen social de las bebidas alcohólicas [Social image of alcoholic beverages]. Adicciones. 2002 Dec; 14(5):115-22. doi: 10.20882/ adicciones. 521

30. Intra MV, Roales-Nieto JG, Moreno San Pedro E. Changes in risk and health behaviors in angentinian university students throughout the educational period. Int ] Psychol Psychol Ther. [Internet] 2011 [cited may 18, 2018];11(1):139-47. Available from: http:// www.redalyc.org/articulo.oa?id=56017110005

31. Morales NB, Plazas M, Sanchez R, Arena CA. Risk and protection factors related to the consumption of psychoactive substances in undergraduate nursing students. Rev. Latino-Am. Enfermagem. 2011;19(Spe):673-83. doi: 10.1590/S0104-11692011000700003

32. Telumbre-Terrero JY, Esparza-Almanza SE, AlonsoCastillo BA, Alonso-Castillo MT. Consumption of alcohol and tobacco in students of nursing. Rev Enferm Actual Costa Rica. 2016;(30). doi: 10.15517/revenf.v0i30.22020 33. García-Moreno LM, Expósito J, Sanhueza C, Angulo MT. Actividad prefrontal y alcoholismo de fin de semana en jóvenes [Pre-frontal activity and weekend alcoholism in young]. Adicciones. 2008;20(3):271-80. doi: 10.20882/adicciones. 269

34. Rodríguez Suárez J, Agulló Tomás E, Agulló Tomás MS. Jóvenes, fin de semana y uso recreativo de drogas: evolución y tendencias del ocio juvenil [Youth, weekend and recreational drug use: evolution and trends of youth leisure]. Adicciones. 2003;15(5):7-34. doi: 10.20882/ adicciones. 451

35. Parada M, Corral M, Caamaño-Isorna $F$, Mota $\mathrm{N}$, Crego A, Rodríguez Holguín $\mathrm{S}$, et al. Definition of adolescent binge drinking. Adicciones. 2011;23(1): 53-63. doi: 10.20882/adicciones. 167

36. Ruiz-Risueño Abad J, Ruiz-Juan F, Zamarripa Rivera JI. Alcohol and tobacco consumption in spanish and mexican adolescent and its relation to physical and sports-related activity and to the family. Rev Panam Salud Publica [Internet] 2012 [cited May 19, 2018]; 31(3):211-20. Available from: https://scielosp.org/pdf/ rpsp/2012.v31n3/211-220/es

37. Caamaño Navarrete F, Alarcón Hormazábal M, Delgado Floody P. Niveles de obesidad, perfil metabólico, consumo de tabaco y presión arterial en jóvenes sedentarios. Nutr Hosp. 2015;32:2000-6. doi: 10.3305/ nh.2015.32.5.9619.

38. Martínez C, Méndez C, Sánchez M, Martínez-Sánchez JM. Attitudes of students of a health sciences university towards the extension of smoke-free policies at the university campuses of Barcelona (Spain). Gac Sanit. 2017;31(2):132-8. doi: 10.1016/j.gaceta.2016.08.009. 39. Pedrelli, P., Borsari, B., Lipson, S. K., Heinze, J. E., \& Eisenberg, D. Gender differences in the relationships among major depressive disorder, heavy alcohol use, and mental health treatment engagement among college students. J Stud Alcohol Drugs. 2016; 77(4):620-8. doi: 10.15288/jsad.2016.77.620

40. Latimer LA, Batanova M, Loukas A. Prevalence and harm perceptions of various tobacco products among college students. Nicotine Tobacco Res. 2014 May;16(5):519-26. doi: 10.1093/ntr/ntt174

41. Zárate $M$, Zavaleta A, Danjoy D, Chanamé $E$, Prochazka $R$, Salas $M$, et al. Practices of tobacco consumption and other drugs among students of health's sciences of a private university. Lima-Perú. Invest Educ Enferm. [Internet]. 2006 [cited Jun 23, 2018];24(2):72-81. Available from: http://www.scielo. org.co/scielo.php?script=sci_arttext \&pid=S0120$53072006000200008 \&$ lng =en\&tlng=es.

42. Walsh RA, Cholowski K, Tzelepis F, Stojanovski E. Smoking prevalence, attitudes, and confidence about tobacco roles among Australian nursing students. J Addict Nurs. 2012 Oct;23(3):181-90. doi: 10.1097/ JAN.0b013e31826f4b83.

43. Kutlu $Y$, Armstrong $M$, Bostanci N, Yilmaz S, Buzlu S. The Relationships between Substance use and Psychosocial Factors in Turkish Nursing Students. J Addict Nurs. 2008;19(4):201-6. doi: 10.1080/10884600802505047.

44. Ulus T, Yurtseven E, Donuk B. Prevalence of smoking and related risk factors among Physical Education and Sports School students at Istanbul University. Int J Environ Res Public Health. 2012 Mar;9(3):674-84. doi: 10.3390/ijerph9030674

45. Chen X, Li X, Stanton B, Mao R, Sun Z, Zhang $\mathrm{H}$, et al. Patterns of cigarette smoking among students from 19 colleges and universities in Jiangsu Province, China: a latent class analysis. Drug Alcohol Depend. 2004 Nov 11;76(2):153-63. doi: 10.1016/j. drugalcdep.2004.04.013

46. Morrell HE, Cohen LM, Bacchi D, West J. Predictors of smoking and smokeless tobacco use in college students: a preliminary study using web-based survey methodology. J Am Coll Health. 2005 Sep-Oct;54(2):108-15. doi: 10.3200/JACH.54.2.108-115

47. León DD, Silva CC, Oblitas YM. Consumption of snuff and family and friendly relations in female students of pharmacy career. Rev Enferm Herediana. 2016;8(2):52. doi: 10.20453/renh.v8i2.2682.

48. Latorre-Roman PA, Gallego-Rodriguez M, MejiaMeza JA, Garcia-Pinillos F. Alcohol, and tobacco consumption and sports practice in Mexican and Spanish university students and the association between quality of life and health and sensation seeking. Gac Med Mex. [Internet]. 2015 Mar-Apr [cited Jan 27, 2018];151(2):197-205. Available from: https:// dialnet.unirioja.es/servlet/articulo?codigo $=5168969$ 
49. Krauss MJ, Cavazos-Rehg PA, Plunk AD, Bierut LJ, Grucza RA. Effects of state cigarette excise taxes and smokefree air policies on state per capita alcohol consumption in the United States, 1980 to 2009. Alcohol Clin Exp Res. 2014;38(10):2630-8. doi: 10.1111/acer.12533.

50. Seo DC, Torabi MR, Chin MK, Lee CG, Kim N, Huang $\mathrm{SF}$, et al. Physical activity, body mass index, alcohol consumption and cigarette smoking among East Asian college students. Health Educ J. 2014 Jul;73(4):453-65. doi: 10.1177/0017896913485744

51. VanKim NA, Laska MN, Ehlinger E, Lust K, Story M. Understanding young adult physical activity, alcohol and tobacco use in community colleges and 4-year postsecondary institutions: A cross-sectional analysis of epidemiological surveillance data. BMC Public Health. 2010 Apr 26;10:208. doi: 10.1186/1471-2458-10-208. 52. Joung MJ, Han MA, Park J, Ryu SY. Association between Family and Friend Smoking Status and Adolescent Smoking Behavior and E-Cigarette Use in Korea. Int J Environ Res Public Health. 2016 Nov 25;13(12). doi: 10.3390/ijerph13121183

53. Molanorouzi K, Khoo S, Morris T. Motives for adult participation in physical activity: type of activity, age, and gender. BMC Public Health. 2015;15:66. doi: 10.1186/s12889-015-1429-7.

54. Concha-Cisternas $Y$, Guzmán-Muñoz E, ValdésBadilla P, Lira-Cea C, Petermann F, Celis-Morales C. Factores de riesgo asociados a bajo nivel de actividad física y exceso de peso corporal en estudiantes universitarios. Rev Médica Chile. 2018;146:840-9. doi: 10.4067/s0034-98872018000800840.

55. Musaiger AO, Awadhalla MS, Al-Mannai M, AISawad M, Asokan GV. Dietary habits and sedentary behaviors among health science university students in Bahrain. Int J Adolesc Med Health. 2017 Apr 1;29(2). doi: 10.1515/ ijamh-2015-0038.

56. Doyle CB, Khan A, Burton NW. Recreational physical activity context and type preferences among male and female Emirati university students. Int Health. 2019 Feb 14. doi: 10.1093/inthealth/ihz002.

57. Telleria-Aramburu N, Sanchez C, Ansotegui L, Rocandio AM, Arroyo-Izaga M. Influence of sport practice and physical exercise on anthropometric indicators and weight satisfaction in men university students: a pilot study. Nutr Hosp. 2014 Oct 3;31(3):1225-31. doi: $10.3305 / \mathrm{nh} .2015 .31 .3 .8148$
58. Snyder K, Lee JM, Bjornsen A, Dinkel D. What Gets Them Moving? College Students' Motivation for Exercise: An Exploratory Study. Recreat Sports J. 2017 Oct;41(2):111-24. doi: 10.1123/rsj.2017-0026

59. Toselli S, Spiga F. Sport practice, physical structure, and body image among university students. J Eating Disorders. 2017;5:31. doi: 10.1186/s40337-017-0163-1 60. García Ferrando M. Posmodernidad y Deporte: Entre la individualización y la masificación. Encuesta sobre hábitos deportivos de los españoles 2005 [Postmodernity and Sport: Between individualization and massification. Survey on sports habits of Spaniards 2005]. Madrid: Consejo Superior de Deportes-Centro de Investigaciones Sociológicas; 2006. ISBN: 9788474764062.

61. Manz K, Mensink GBM, Finger JD, Haftenberger M, Brettschneider AK, Lage Barbosa $C$, et al. Associations between Physical Activity and Food Intake among Children and Adolescents: Results of KiGGS Wave 2. Nutrients. 2019 May 11;11(5). doi: 10.3390/nu11051060

62. Alkerwi A, Baydarlioglu B, Sauvageot N, Stranges $S$, Lemmens $P$, Shivappa $N$, et al. Smoking status is inversely associated with overall diet quality: Findings from the ORISCAV-LUX study. Clin Nutr. 2017 Oct; 36(5):1275-82. doi: 10.1016/j.clnu.2016.08.013

63. Kim EK, Kim H, Vijayakumar A, Kwon O, Chang N. Associations between fruit and vegetable, and antioxidant nutrient intake and age-related macular degeneration by smoking status in elderly Korean men. Nutr J. 2017 Dec 4;16(1): 77. doi: 10.1186/s12937-017-0301-2
Received: Dec $18^{\text {th }} 2018$

Accepted: Sept 16 2019
Copyright $\odot \mathbf{2 0 2 0}$ Revista Latino-Americana de Enfermagem This is an Open Access article distributed under the terms of the Creative Commons (CC BY).

This license lets others distribute, remix, tweak, and build upon your work, even commercially, as long as they credit you for the original creation. This is the most accommodating of licenses offered. Recommended for maximum dissemination and use of licensed materials. 